\title{
Analyzing the employment of expatriates as high-performance workers in terms of their impact on selected areas of the company.
}

\author{
Jana Cocul'ová1,*, L’uba Tomčíková ${ }^{2}$ \\ ${ }^{1}$ University of Prešov in Prešov, Faculty of Management, Department of Management, \\ Konštantínova 16, 08001 Prešov, Slovakia \\ ${ }^{2}$ University of Prešov in Prešov, Faculty of Management, Department of Management, \\ Konštantínova 16, 08001 Prešov, Slovakia
}

\begin{abstract}
The central topic of the paper is human resource management in multinational companies as one of the consequences of globalization. The paper particularly focuses on the use of expatriates as highperformance workers. The aim of the paper is to provide an analytical view of the work of this type of employees in branches of multinational organizations operating in Slovakia. The paper presents research results aimed at analyzing the employment of expatriates in branches of multinational companies in terms of selected features (size of branch, how long the company operates on the Slovak market and number of branches of an multinational company) and finding statistically significant links between the time an expatriate spends in the country and the impact he/she has on selected aspects of the company, namely innovation and new knowledge, his/ her share in addressing business challenges and on relationships at work from the perspective of branch managers of multinational companies. The research was conducted between January and May 2019 using a standardized questionnaire method on a sample of 138 managers of branches in which expatriates worked. The obtained data were processed by the methods of descriptive statistics and Chi-square test, through which three research hypotheses were tested.
\end{abstract}

\section{Introduction}

Globalization and the need to operate in an international environment have become part of the daily routine of many companies. A typical feature of international companies is the employment of a mix of employees, both local employees from the host country and expatriates from the country the parent company is located in. Expatriates pose a difficult task for organizations because of the existence of differences in language, culture, values or expectations. These differences, resulting from a different cultural or institutional environment, are likely to affect the way of work and the success of expatriates. Expatriates fall into the category of high-performance workers due to the difficulty and specificity of the job they have to perform abroad. For an expatriate to be able to deliver maximum

* Corresponding author: jana.coculova@unipo.sk 
performance and be productive, the company must create the most appropriate conditions for a successful adaptation in the host country. Many scientists emphasize the specific skills that expatriates should possess, while pointing out the importance of preparing these employees to work abroad [1-3].

\section{Theoretical framework}

Due to the increasing use of expatriates as a result of globalization, expatriates need to have knowledge of the legislative environment not only of the home country but also of the host country and have knowledge of the human resource management practices that vary widely from country to country. They need to be able to communicate effectively in different cultures, to gain the trust of local diverse staff speaking different languages. As organizations are expanding globally, the number of variables they need to handle is growing exponentially, and therefore change management becomes a major challenge [4].

Posting of workers from the mother country to the country where the branch is located is a very common phenomenon, even for those companies without total ethnocentric approach. Posting of the employee, the expatriate, is the initial stage in the implementation of international activities. Tung gives the following reasons for posting employees [5]:

- compensation for missing experts and managers in the host country; highperformance workers,

- the need to transfer management, product, knowledge know-how,

- guarantees of an efficient communication and information structure,

- personnel and organizational development,

- the development of a cross-border corporate culture.

Expatriates are important in moving information between branches, fulfilling the objectives of the parent company and are also a tool of control and coordination. A wellprepared and successful expatriate can deliver positive business results to the company. With the help of an expatriate, the company can expand its know-how and develop internal communication within the company. However, it is important to realize that not every expatriate's trip is a success and it may happen that the expatriate abroad will fail, which is one of the main risks of posting. However, posting is an opportunity for an individual to expand and advance his career. Expatriates are motivated either financially, by career growth or by the opportunity to gain new experience. In this respect, we divide expatriates into those who have to go abroad as part of their job position and those who have chosen this option themselves and see the possibility of enriching their lifestyle [6]. However, although the expatriate's failure rate may not be as high as often reported [7], the impact they have is often far from ideal [8]. The failure of an expatriate is a major problem not only from the perspective of the employee himself, but also from the perspective of costs associated with the failure abroad $[9,10]$. Therefore, companies should be highly motivated to prepare expatriates for their new position in an effort to minimize possible failures. This can be achieved by focusing on two stages in this regard [11]. In the first stage, during selection and training process, and then in the second stage, after an expatriate arrives in the host country, when expatriates begin to communicate with the host and begin adapting their behavior to the cultural standards and customs of the host country [12]. Selmer states that behavioral training is more effective on arrival than before leaving because expatriates tend to be more motivated to learn when they are directly in the new environment and face new challenges [13].

Expatriates also perform contact and coordination functions between the parent company and its subsidiaries, as they know the company's standards, values and ways of conducting operations. The contact role is important in terms of evaluating and translating information addressed by headquarters to its branches and for transferring various types of 
information and feedback from branches to other parts of the company. The third important role of expatriates is that they can provide the subsidiary with the technological and administrative knowledge that the parent company considers crucial to the efficient operation of the branch. The primary strategic challenge for any international company is therefore the selection of expatriates who can perform effectively in each of these three tasks [14].

The success of a foreign task depends mainly on the effectiveness of intercultural education, since precise intercultural education can help reduce psychological stress and intercultural shock, which often causes failure of expatriates [15]. The successful application of an intercultural learning model can help employees become familiar with the values, rules, beliefs, working style and other aspects of the world, and thus facilitate the adaptation of employees during posting [16]. Intercultural training includes ethnographic studies (study of the country to which the expatriate is posted, facts, geography, economics, history), cultural assimilation program (model situations in which the employee has the opportunity to train the responses appropriate to the culture), foreign language courses and various psychological trainings for coping with crisis situations. Also, as a form of preparation, short business trips to the country to which the expatriate will be sent later are also an option [17].

The inability of expatriates in managerial positions to adapt to the new environment is cited as the main reason for the expatriate's failure to work in a foreign country, including both adaptation to the working environment and adaptation to the outside environment (outside the work environment) [18]. One can therefore speak of general adaptation which represents a degree of adaptation to general living conditions such as diet, weather, housing and transport [2]. Work adaptation is related to the psychological comfort in a new working environment influenced by different working values, expectations and responsibilities [20].

The adaptation of the expatriate is an essential aspect of the success of the international company, as several studies show that the degree of adaptation is statistically positively related to the expatriate's performance, which in turn has a positive impact on the competitiveness of the company [19]. Several studies have focused on investigating the factors determining the level of adjustment of expatriates, one of which was the training of expatriates [20]. Authors report that effective expatriates should be able to understand the host country's dynamic environment and employ the host society's tacit knowledge [21].

\section{Methodology}

The Slovak market features a large number of international companies represented by their branches. Thus, Slovakia is home to expatriates working in those companies. Their stay in Slovakia has become a central topic of the research presented in the paper. The aim of the paper was to provide an analytical view of the work of expatriates in subsidiaries of international companies operating in the Slovakia. The research pursued two subobjectives: (1) to determine the level of expatriate utilization at the branches of international companies in terms of selected features (branch size, duration of operation on the Slovak market and the number of subsidiaries of an international company); and (2) identify statistically significant relationships between the length of the stay of expatriates and their impact on selected areas of the company, namely (a) innovation and new knowledge, (b) problem solving and (c) workplace relationships from the perspective of branch managers. The research was conducted between January and May 2019 using a standardized questionnaire method on a sample of 138 branch managers whose companies employ expatriates. The research also focused on the length of expatriates' stay in the branch as an independent variable: up to 3 months; 3 - 6 months; 6-12 months; 1 - 2 years; 3 years or more. The perceived impact of expatriates on selected areas was measured using 
the following scale: 1 -strongly positive, 2 - positive, 3 - neutral, 4 - negative, 5 -strongly negative. The questionnaire was distributed personally and electronically. The obtained data were processed by methods of descriptive statistics and Chi-squared test and used to test 3 research hypotheses.

\section{Results and discussion}

The first partial objective of the research was to find out the situation in the field of expatriate use in terms of 3 identifying features of branches of international companies operating in the Slovak Republic.

The first identifier examined is the size of the branch, expressed in terms of the number of employees. As shown in Figure 1, the use of expatriates is typical especially for branches that employ a higher number of employees. The largest number of branches who use expatriates are companies with 500 or more employees, and there is no single branch that falls into the category of small businesses. It can therefore be assumed that branches with a higher number of employees are more demanding in terms of management, coordination and control by the parent company, which may be the reason for sending an expatriate to the country where the branch is located to act as an intermediary between the parent company and the host country.

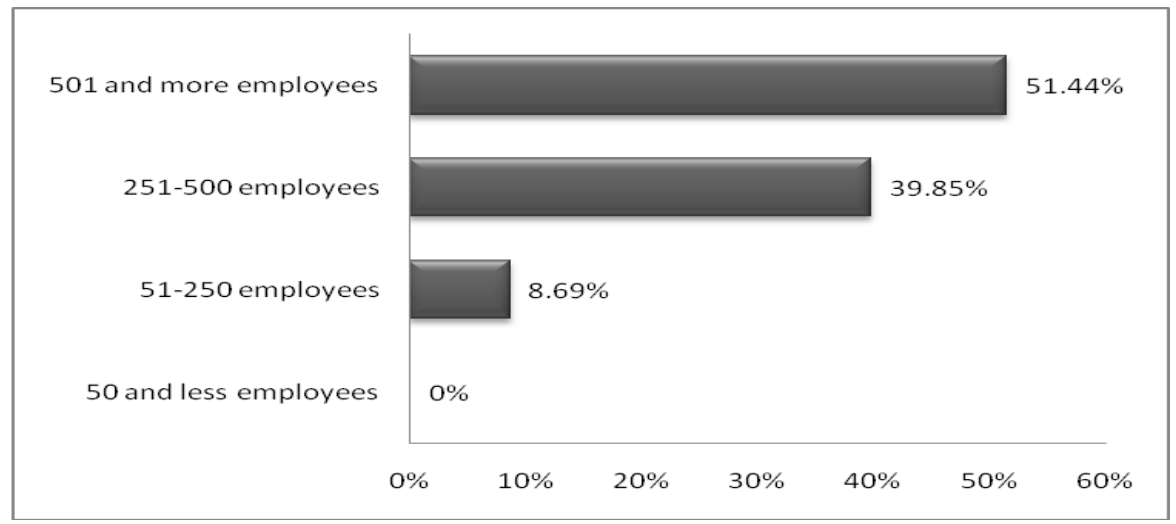

Fig. 1. Expatriate use in terms of branch size.

The second identifier that was the subject of the research is the period of operation of the branch on the Slovak market. We were interested in the share of expatriates in branches with different length of market operation. According to the results, we found that the most expatriates are used by branches operating on the market for 1 - 5 years, i.e. for a relatively short time. An interesting finding is also the fact that branches operating on the Slovak market for a long time, that is 11 years or more, use the expatriates only to a small extent. It may be assumed that the use of expatriates is more common in younger companies, perhaps because expatriates are often used during periods of company formation or development to transfer the required know-how from headquarters to the host country. 


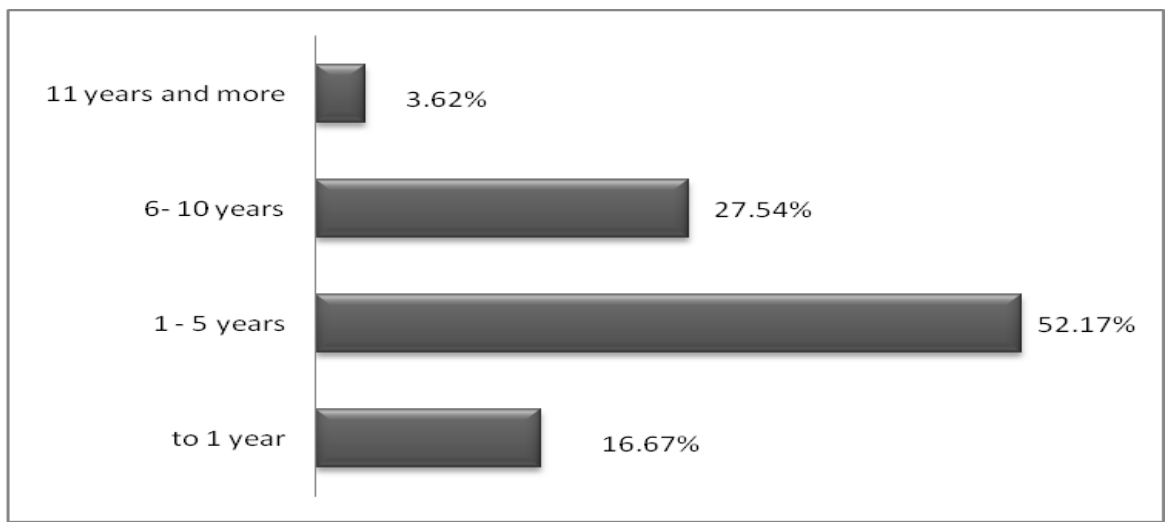

Fig. 2. Expatriate use in terms of duration of market presence.

When analyzing the state of employment of expatriates, attention was also paid to the total number of branches that the international company has in all countries (not only in Slovakia). We were wondering whether companies with more branches would be more likely to use expatriates than companies with fewer branches. The results show that, in the research sample, companies that own a large number of branches across the country, 11 or more, are more likely to employ expatriates. Conversely, companies with fewer branches use expatriates to a lesser extent. Obviously, companies with offices in different countries are more often forced to post their employees to other countries because of the need for coordination, more efficient management, the transfer of the required knowledge and resources and the like.

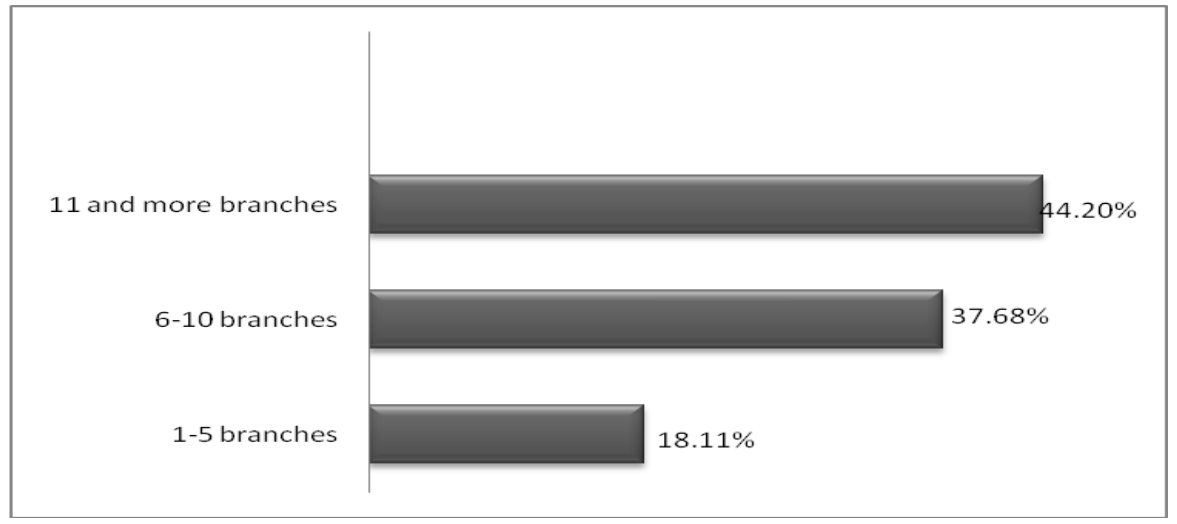

Fig. 3. Expatriate use in terms of number of branches.

The second research objective focused on the analysis of the impact of expatriate activities in terms of perception of managers of branches of international organizations operating in the Slovak Republic. The first dependent variable is the perception of the expatriate's impact in terms of the transfer of innovation and new knowledge to the branch. It has been assumed that the longer the expatriate operates at the branch, the more positive his impact on innovation and knowledge he has.

H1: We assume a statistically significant correlation between the length of expatriate's stay and the impact on innovation and new knowledge in the branch from the point of view of branch managers.

The results of testing the hypothesis $\mathrm{H} 1$ using the Chi-square test are shown in Table 1. 
Table 1. Testing hypothesis H1

\begin{tabular}{|c|c|c|}
\hline Compared value $\alpha$ & Chi-square & p-value \\
\hline 0.05 & 23.32 & 0.02509124 \\
\hline
\end{tabular}

Based on the results of statistical testing, H1 is accepted, since $\mathrm{p}$ value $<0.05$, therefore it can be confirmed that there is a relationship between the length of expatriate's stay and his impact on innovation and new knowledge in the branch.

We were also curious whether expatriates may help in solving problems in the branch. The expatriate is often sent to the host country to address certain, in particular strategic problems related to the operation of the branch.

$\mathrm{H} 2$ : We assume a statistically significant link between the length of expatriate's stay and his impact on problem-solving from the point of view of branch managers.

The results of testing hypothesis $\mathrm{H} 2$ are shown in Table 2.

Table 2. Testing hypothesis $\mathrm{H} 2$

\begin{tabular}{|c|c|c|}
\hline Compared value $\alpha$ & Chi-square & p-value \\
\hline 0.05 & 21.18 & 0.0477791 \\
\hline
\end{tabular}

At a level of significance of $\alpha 0.05$, a Chi-squared value of 21.18 was found, which is translated as p-value 0.0477791 . The value is lower than 0.05 , and it thus means that the hypothesis $\mathrm{H} 2$ was accepted. It can be confirmed that the length of expatriate's stay affects the perception of the expatriate by branch managers in terms of problem solving (either negatively or positively).

An important variable that can be influenced by expatriates are workplace relations. Workplace relations are influenced by the attitude of local employees towards the expatriate, so it is very important for the expatriate to know the branch's corporate culture, its standards and attitudes in order to adapt to the branch's environment. Our aim was to find out whether the length of the expatriate's stay influences workplace relations from the point of view of branch managers.

H3: We assume a statistically significant correlation between the length of expatriate's stay and the impact on workplace relationships from the point of view of branch managers.

The hypothesis was tested using the Chi-square test, see Table 3.

Table 3. Testing hypothesis $\mathrm{H} 3$

\begin{tabular}{|c|c|c|}
\hline Compared value $\alpha$ & Chi-square & p-value \\
\hline 0.05 & 21.43 & 0.0444 \\
\hline
\end{tabular}

The hypothesis H3 is accepted because $\mathrm{p}=0.044$. It can be confirmed that the length of expatriate's stay influences the workplace relations at the branch.

The hypotheses were confirmed for all 3 variables examined. It is clear that the length of expatriate's stay is an important determinant that affects the perception of the expatriate's impact on selected business areas, namely the impact on innovation, knowledge, problem solving and workplace relationships. It is the responsibility of the company to assess the length of expatriate's stay in the host country in the light of the role the expatriate is to perform at the branch. As adaptation, either by the expatriate or by local employees, takes time, it can be assumed that longer stays create better conditions for mutual cooperation between the expatriate and local employees. 


\section{Conclusions}

Expatriates represent a category of high-performance employees whose utilization rate is steadily increasing. Due to the growing number of international organizations in Slovakia, the number of expatriates in the Slovak environment is also increasing. The research carried out under the conditions of the Slovak Republic has shown that expatriates are mainly used by branches with a higher number of employees and international companies that own several branches. Expatriates are responsible for performing important tasks in the host country, which further increases the burden placed upon them. Preparing the expatriate for his mission in the host country is extremely important as it affects the success of his stay. It is the task of the international company to assess the length of expatriate's stay so that it has a positive impact on the branch in which he operates. Statistical analysis of data obtained from the research confirmed that from the point of view of branch managers, the length of expatriate's stay influences important business areas, namely innovation and knowledge, problem solving and workplace relationships.

The paper has been elaborated under Grant VEGA 1/0237/19.

\section{References}

1. R.L. Tung, A Contingency Framework of Selection and Training of Expatriates Revisited. Human Resource Management Review, 8, 1 (1998)

2. J.S. Black, M. Mendenhall, Cross-Cultural Training Effectiviness: A Review and a Theoretical Framework for Future Research. Academy of Management Review, 15, 1 (1990)

3. P. Caliguiri, V. Di Santo, Global Competence: What is It, and Can It be Developed Through Global Assignments? Human Resource Planning, 24, 3 (2001)

4. D. Egerová, Talent v organizačním prostředí-teoretické přistupy a implikace pro talent management. Trendy v podnikaní, Busines Trends, 5, 1 (2015)

5. R.L. Tung, Selection and training of personnel for overseas assignment. Columbia Journal of World Business, 16 (2001)

6. V. Cejthamr, J. Dědina, Management a organizační chováni, GradaPublishing (2010)

7. A.W. K. Harzing, The persistent myth of high expatriate failure rates. International Journal of Human Resource Management, 6, 2 (1995)

8. J. Osland, A. Osland, Expatriate paradoxes and cultural involvement. International Studies of Management and Organization, 35, 4 (2005)

9. J. Lauring, J. Selmer, Person-environment fit and emotional control: Assigned expatriates vs. self-initiated expatriates. International Business Review, 27, 5 (2018)

10. H. Heizmann, A. Fee, S.J. Gray, Intercultural Knowledge Sharing Between Expatriates and Host-country Nationals in Vietnam: A Practice-based Study of Communicative Relations and Power Dynamics. Journal of International Management, 24, 1 (2018)

11. J. Selmer, I. Torbiorn, C.T. de Leon, Sequential cross-cultural training for expatriate business managers: predeparture and post-arrival. International Journal of Human Resource Management, 9, 5 (1998)

12. Z. Aycan, Acculturation of Expatriate Managers: A Process Model of Adjustment and Performance. New Approaches to Employee Management, 4 (1997)

13. J. Selmer, The preference for predeparture or postarrival cross-cultural training: an exploratory approach. Journal of Managerial Psychology, 16, 1 (2001) 
14. V. Suutari, Ch. Brewster, L. Makela, et al., The Effect of International Work Experience on the Career Success of Expatriates: A Comparison of Assigned and SelfInitiated Expatriates. Human Resource Management, 57, 1 (2018)

15. S. Davidekova, M. Gregus, Impacts of globalization on socio-economic domain of employees. International Scientific Conference Globalization and Its Socio-Economic Consequences, University of Zilina, The Faculty of Operation and Economics of Transport and Communications (2017)

16. M. Jannesari, Z.M. Wang, J. McCall, B.Y. Zheng. Psychological Availability between Self-Initiated Expatriates and Host Country Nationals during Their Adjustment: The Moderating Role of Supportive Supervisor Relations. Frontiers in Psychology, 8, 2049 (2017)

17. P. Štrach, Medzinárodní management, Praha, Grada Publishing (2009)

18. D. Harrison, M. Shaffer, Mapping the criterion space for expatriate success: task-and relationship-based performance, effort and adaptation. The International Journal of Human Resource Management, 16, 8 (2005)

19. P. Durana, D. Chlebikova, The influence of globalization for job analysis. International Scientific Conference Globalization and Its Socio-Economic Consequences, University of Zilina, The Faculty of Operation and Economics of Transport and Communications (2017)

20. I. Ali, M. Ali, L. Antonio Leal-Rodriguez, G. Albort-Moranti, The role of knowledge spillovers and cultural intelligence in enhancing expatriate employees' individual and team creativity. Journal of Business Research, 101 (2019)

21. J.B. Abugre, Y.A. Debrah, Assessing the impact of cross-cultural communication competence on expatriate business operations in multinational corporations of a SubSaharan African context. International Journal of Cross Cultural Management, 19, 1 (2019) 